\title{
Heavy Metals Accumulation in Surface Waters, Bottom Sediments and Aquatic Organisms in Lake Mainit, Philippines
}

\author{
Emalina L. Ebol ${ }^{1, a^{*}}$, Carlos H. Donoso ${ }^{2, b}$, Rex Bombet D. Saura ${ }^{1, c}$ \\ Rolit Joan C. Ferol ${ }^{1, \mathrm{~d}}$, Juliet Ruth D. Mozar ${ }^{1, \mathrm{e}}$, Arman N. Bermon ${ }^{3, \mathrm{f}}$, \\ Jerry Manongas ${ }^{3,9}$ Joan Christine H. Libot ${ }^{4, h}$, Cara Jane Matabilas ${ }^{4, i}$, \\ Joycelyn C. Jumawan ${ }^{4, j}$ and Rey Y. Capangpangan ${ }^{5, k}$
}

${ }^{1}$ Department of Teacher Education, Surigao State College of Technology- Mainit Campus, Magpayang Mainit, SDN, Philippines

${ }^{2}$ College of Engineering, Surigao State College of Technology-Main Campus

${ }^{3}$ Department of Agriculture, Surigao State College of Technology-Mainit Campus, Magpayang, Mainit, SDN, Philippines

${ }^{4}$ Department of Biology, Caraga State University-Main Campus, Ampayon, Butuan City, Philippines

${ }^{5}$ Department of Chemistry, Caraga State University-Main Campus, Ampayon, Butuan City, Philippines

aebolemalina@gmail.com, ${ }^{\mathrm{b}} \mathrm{carlos}$ _donoso2008@yahoo.com ${ }^{\mathrm{c}}$ rexbombet@gmail.com

dyanyanferol@gmail.com ejdmozar@gmail.com , farman.bermon21@gmail.com, 9manongasjerry@gmail.com hjoanchristinelibot17@gmail.com icara.matabilas@carsu.edu.ph j*joycejumawan1981@gmail.com, kreycapangpangan@gmail.com

Keywords: Lake Mainit, Heavy metals, freshwater fishes, lake invertebrates

\begin{abstract}
Lake Mainit is one of the largest lakes recognized as one of Key Biodiversity Areas (KBAs) in the Philippines with rich fishery resources. However, the lake is at risk from heavy metal contamination due to inputs of industrial, agricultural effluents and small-scale mining activities. The present work evaluated levels of heavy metals namely cadmium, lead, and mercury from key aquatic fauna and sediments from seven strategic sections of the lake in 2018. Muscle samples of all seven fish species assessed were below detections limits (BDL) for tHg and Cd. Trace concentrations of $\mathrm{Pb}$ in the muscles were detected in Oreochromis niloticus, Glossogobius giuris, Channa striata and Vivipara angularis but values were within safe ranges. Trace concentrations of $\mathrm{Pb}$ in the riverine crab (Sundathelpusa $\mathrm{sp}$ ) exceeded safe limits. Both $\mathrm{Cd}$ and $\mathrm{tHg}$ were below detection limits in the three invertebrates assessed. Traces of $\mathrm{Pb}$ were detected in $\mathrm{S} 4$ (Magtiaco) and $\mathrm{S} 5$ (Jaliobong) below standard limits $(0.05 \mathrm{ppm})$ only during the southwest $(\mathrm{SW})$ monsoon but $\mathrm{Pb}$ were not detected across all stations during the NE monsoon of 2018. For Cd, however, trace concentrations were detected only during the $\mathrm{NE}$ monsoon wherein $\mathrm{Cd}$ in S2 (Mayag), S3 (Magpayang), S4 (Magtiaco), S5 (Jaliobong), S6 (Dinarawan) and S7 (Kalinawan) exceeded standard limits for $\mathrm{Cd}$ in waters $(0.01 \mathrm{ppm})$. Concentrations of $\mathrm{tHg}$ in the water were not detected across the two sampling seasons in all seven tributary stations. In sediments, $\mathrm{Pb}$ were all detected during the southwest monsoon with highest $\mathrm{Pb}$ concentrations in $\mathrm{S6}$ (Dinarawan) and $\mathrm{S} 7$ (Kalinawan) which exceeded safe limits. Trace $\mathrm{Cd}$ in sediments were mostly below detectable limits. Concentrations of $\mathrm{tHg}$ in sediments exceeded safe limits during the SE monsoon in S4 (Magtiaco) and S7 (Kalinawan) areas. These findings recommended that continuous heavy metal monitoring must be conducted. It is also strongly suggested to evaluate the presence of heavy metals in other aquatic organisms and assess the ecological risk posed by these heavy metals though heavy metal speciation analysis.
\end{abstract}




\section{Introduction}

Lake Mainit, known as the fourth largest lake in the Philippines, is located in the province of Surigao del Norte and Agusan del Norte, Philippines. About 31 barangays in the four-lakeshore municipalities are dependent on the lake for food and livelihood [1]. The lake supports a thriving fishery resource that is threatened by unsustainable or destructive fishing practices [2]. The environmental perturbations that the lake is experiencing today include prevalent and irresponsible mining, poor agricultural practices, human-induced activities, soil erosion, fishing malpractices, among others. The lake is composed of 28 river tributaries that provide significant inputs to the water body. The activities upstream of these river tributaries also contribute to the existing overall health condition of the lake ecosystem [1].

While large-scale mining was no longer operating near the lake, on-going small-scale gold mining activities in Alegria, Kitcharao and Jabonga were just as problematic in terms of siltation and possible river contamination with heavy metals [1]. Effluents from municipal, industrial and agricultural wastes also enter through various point and non-point sources into the lake [2].

Pollutants are being discharged to rivers and lakes, and ultimately leaches into the soil calls serious attention due to its toxic effect to the environment and to human health. The contamination of heavy metals is a major environmental stress because of its great potential for bioaccumulation $[3,4,5]$. Common toxicants such as cadmium $(\mathrm{Cd})$, lead $(\mathrm{Pb})$ and mercury $(\mathrm{Hg})$ are mostly found in the marine and freshwater environment and the aquatic fauna [6]. Toxicity of these heavy metals may occur at high concentrations when consumed for an extended period [7]. They are considered as one of the industrial threats and one of the dangerous environmental pollutants resulting from agricultural, mining, industrial, anthropogenic activities even from the exhaust smoke emitted by vehicles and fuel through aquatic navigation services [8].

Previous reports have detected lead, cadmium and mercury in the Lake Mainit waters but the levels were not in alarming concentrations [9]. A widespread fish kill in 2015 affecting mostly tilapia Oreochromis niloticus and carp Cyprinus carpio was reported in the lake due to low dissolved oxygen but levels of heavy metals in the water and fish were not determined during the incident [10]. Due to the pressing environmental stress to Lake Mainit, e.g. prone to the substantial load of pollutants from its surrounding environs, this study was conducted and focused on the determination of the concentration level of Lead $(\mathrm{Pb})$, Cadmium $(\mathrm{Cd})$ and total Mercury $(\mathrm{Hg})$ in surface water, bottom sediment and other aquatic fauna.

\section{Materials and Methods}

\section{Study Area}

Lake Mainit is situated in the municipalities of Mainit, Alegria, Kitcharao, and Jabonga. The sampling stations were selected based on the significance of the locations and based on the experimental design following ecological settings, population density, land uses and human activities in the area. Seven strategic stations within the lake serving as tributaries from upstream were established (S1-Tagbuyawan; S2- Mayag; S3-Magpayang; S4-Magtiaco; S5- Jaliobong; S6Dinarawan; S7- Kalinawan) (Figure 1). All stations established were active areas utilized for fishing and navigation by boat. Lakeshore adjacent these stations are mostly residential (Dinarawan) or agricultural (Tagbuyawan, Mayag, Magpayang, Magtiaco, Jaliobong, Kalinawan) mostly of rice, cornfields and grasslands. A small scale gold processing area was situated near Tagbuyawan station while a large scale gold mine can be found upstream the Magpayang station tributary. A small scale gold mining activity can be found upstream the Magtiaco station. The Kalinawan station is where Lake Mainit drains to Kalinawan River. Cattails dominated the littoral zone of this station whereas a lake resort and cluster of residential houses of the Municipality of Jabonga can be found nearby. The Dinarawan station has rocky riverbanks and stony substrate. Indigenous (Mamanwa) settlements and a nearby hydropower plant can be found near this station. 


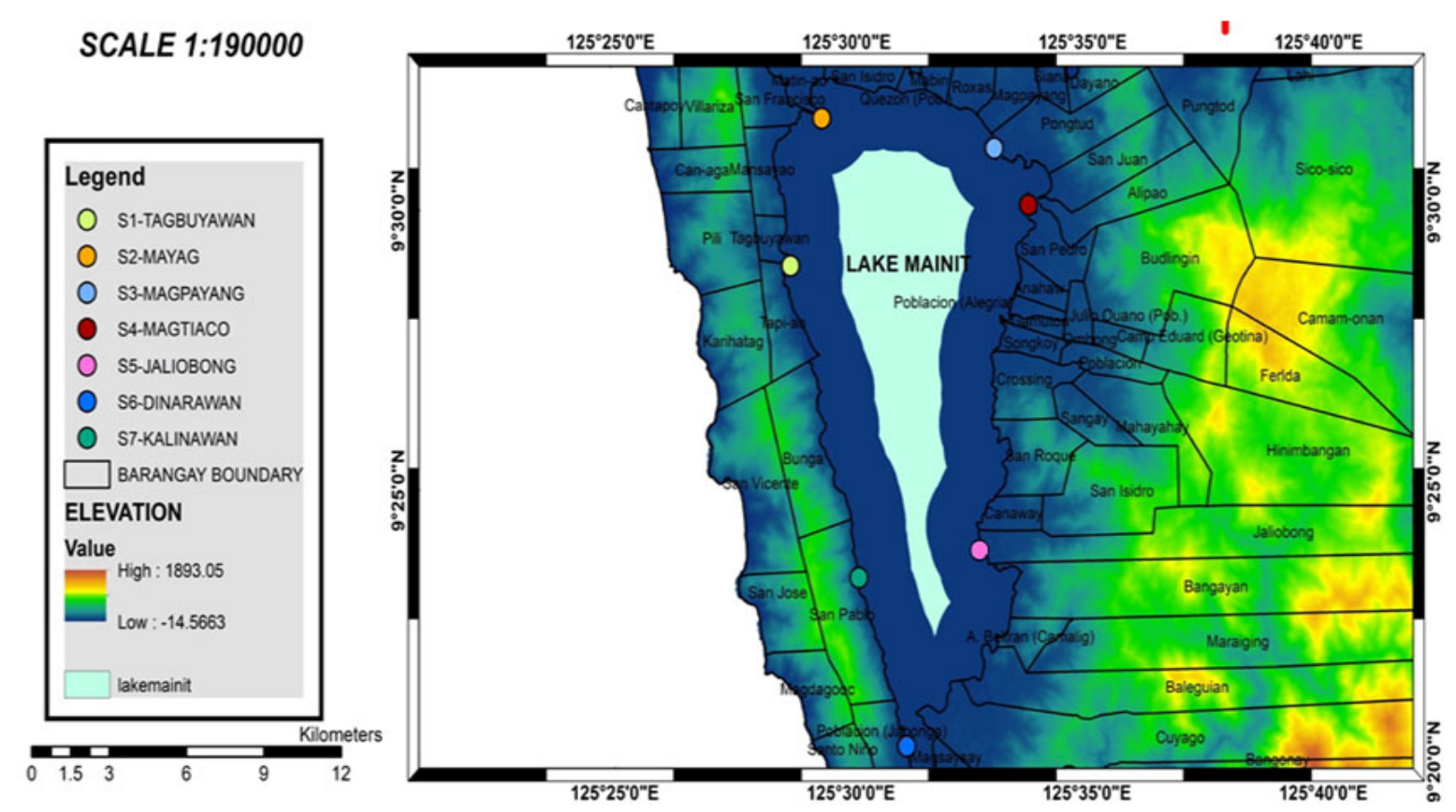

Figure 1. Study stations established in Lake Mainit, Philippines

\section{Collection of representative aquatic fauna}

Fishes and other aquatic fauna were collected depending on their availability from June to December 2018. Seven fish, two mollusks and one crab species found abundantly in Lake Mainit were selected for determination of $\mathrm{Pb}, \mathrm{Cd}$ and $\mathrm{Hg}$ (Table 1). All seven fish species were sold commercially in the vicinity of Lake Mainit. Vivipara angularis and Corbicula fluminea are local delicacies. The meat of the riverine crab Sundathelpusa sp is often used as bait for catching fish. Similarly sized- individuals of each fish species were caught in replicates using cast nets or hook and line. The bivalves, gastropods and crabs were purposively collected alive in sections of the lake where they are abundant. The bivalve Corbicula fluminea and snail $V$. angularis were collected by hand or by dip nets. The crab Sundathelpusa sp. were collected by hand underneath rocks, decayed logs and vegetation nearest the lakeshore or through traps. Samples were weighed (g) using a digital weighing scale and its total body length (TL) was measured (in $\mathrm{cm}$ ) using a ruler. Sex of the samples were not determined. Samples were placed in an ice-cooled container for transportation to the laboratory where they were frozen until being processed for analysis.

Table 1. Aquatic fauna from Lake Mainit determined for $\mathrm{Pb}, \mathrm{Cd}$ and $\mathrm{Hg}$ concentration

\begin{tabular}{lccc}
\hline \multicolumn{1}{c}{ Species } & Family & Common Name & Diet Preference \\
\hline Glossogobius giuris & Gobiidae & Pijanga & Carnivorous \\
Oreochromis niloticus & Cichlidae & Tilapia & Omnivorous \\
Channa striata & Channidae & Haluan & Carnivorous \\
Cyprinus carpio & Cyprinidae & Carpa & Detritivorous \\
Clarias batrachus & Clariidae & Bangkok/Hito & Omnivorous \\
Hypseleotris agilis & Eleotridae & Bugwan & Carnivorous \\
Anguilla marmorata & Anguillidae & Kasili & Carnivorous \\
Corbicula fluminea & Cyrenidae & Freshwater clam & Filter feeder, mostly algae \\
Vivipara angularis & Viviparidae & Viviparid snail & Plankton, organic debris \\
Sundathelphusa sp. & Gecarcinucidae & Riverine crab & Generally omnivore \\
\hline
\end{tabular}




\section{Water Sampling}

Water samples from seven (7) identified sampling sites were collected following an established standard protocol [11,12]. Briefly, water samples were collected by grab sampling technique. Sample collection were done early morning (around 7:00 - 9:00) for two sampling periods during Southwest and Northwest Monsoon on July and December of 2018, respectively. Approximately, 1 liter of water was collected in each sampling station from below the water surface. Water samples were acidified to $\sim \mathrm{pH}=2$ using nitric acid and stored in an acid-washed polyethylene bottles and placed in a chilled container during transportation.

\section{Sediment Sampling}

Sediment samples $(\sim 1 \mathrm{~kg})$ were sampled according to the protocol for sediments [13]. Bottom sediments were collected by grab sampling technique in the same stations where water samples were collected for two sampling periods. Sample collection were done using an improvised PVC shovel/scoop sampler from the top 10-20 cm sediment zone. Sediment samples (obtained in triplicates) were sealed in the ziplock plastic container (previously cleaned with $10 \%$ nitric acid) and placed in a chilled container during transport.

\section{Sample preparation and analysis}

Water samples were homogenized by mixing prior to wet digestion. Also sediment samples (about $1 \mathrm{~kg}$ ) were air dried and powderized prior to wet digestion. The fish samples were processed and the muscle tissue was ash-dried and digested via acid digestion process. Crustacean (whole body part) and molluscs (flesh) were also digested following the same digestion protocol as described in the Official Method for Analysis of AOAC [14]. The total concentrations of $\mathrm{Cd}$ and $\mathrm{Pb}$ in water, sediments, fish and other aquatic fauna were assessed using Atomic Absorption Spectrometry (AAS) method while Cold Vapor AAS was used for the analysis of $\mathrm{Hg}$. The analytical concentrations of the target analytes were determined using the standards solutions of the respective metal. Deionized water was used for the dilution of the samples. All calculations were blank-corrected.

\section{Statistical Analysis}

Data were expressed as mean values \pm SEM from replicates of fish, water and sediment samples. Comparisons of levels of each heavy metals were made using one-way ANOVA followed by Tukey's Post hoc test. The Levene's test with the significant level at $p \leq 0.05$ was adopted to determine the homogeneity of variances in terms of ANOVA tests.

\section{Results}

\section{Lead, cadmium and total mercury in selected aquatic fauna}

Length-weight size ranges and levels of $\mathrm{Pb}, \mathrm{Cd}$ and $\mathrm{tHg}$ of selected aquatic fauna are reported in Table 2. Trace concentrations ( $\mathrm{ppm})$ of $\mathrm{Pb}$ in muscles were only detected in O. niloticus, G. giuris, $C$. striata and $V$. angularis but values were within permissible limits for fish $(\leq 0.5 \mathrm{ppm})$ and snail muscles [15]. Levels of $\mathrm{Pb}$ in the Sundathelpusa sp. exceeded safe limits for crab muscles $(0.5 \mathrm{ppm})[16]$. Both $\mathrm{Cd}$ and $\mathrm{tHg}$ were BDL in all aquatic fauna assessed. 
Table 2. Levels of $\mathrm{Pb}, \mathrm{Cd}$ and $\mathrm{tHg}(\mathrm{mg} / \mathrm{kg})$ in muscles of selected aquatic fauna from Lake Mainit, Philippines

\begin{tabular}{llllccc}
\hline \multicolumn{1}{c}{ Species } & n & Length $(\mathbf{c m})$ & Weight $(\mathbf{g})$ & Lead & Cd & Hg \\
\hline G. giuris & 30 & $65.2 \pm 5.3$ & $18.9 \pm 0.7$ & $0.35 \pm 0.00$ & BDL & BDL \\
C. striata & 9 & $33.9 \pm 3.7$ & $357.9 \pm 18.5$ & $0.49 \pm 0.00$ & BDL & BDL \\
C. batrachus & 6 & $31.8 \pm 3.2$ & $236.7 \pm 33.3$ & BDL & BDL & BDL \\
O. niloticus & 9 & $23.7 \pm 1.4$ & $222.8 \pm 31.9$ & $0.27 \pm 0.01$ & BDL & BDL \\
C. carpio & 6 & $51.8 \pm 6.2$ & $2025 \pm 38.7$ & BDL & BDL & BDL \\
A. marmorata & 3 & $88.8 \pm 2.1$ & $1700 \pm 711.8$ & BDL & BDL & BDL \\
H. agilis & 6 & $5.0 \pm 1.6$ & $7.2 \pm 0.6$ & BDL & BDL & BDL \\
C. fluminea & 30 & $4.4 \pm 1.8$ & $2.10 \pm 0.3$ & BDL & BDL & BDL \\
V. angularis & 6 & $2.88 \pm 0.09$ & $5.18 \pm 0.41$ & $0.52 \pm 0.00$ & BDL & BDL \\
Sundathelpusa sp. & 20 & $3.9 \pm 1.6$ & $2.1 \pm 0.5$ & $0.60 \pm 0.05$ & BDL & BDL \\
\hline FAO, 1983 [15] & & & & 0.5 & 0.05 & 0.5 \\
FAO/WHO 1984[16] & & & & 0.5 & & \\
\hline BDL; bew
\end{tabular}

BDL; below detection limit for $\mathrm{Hg}$ and $\mathrm{Cd}$ in muscles: less than $0.02 \mathrm{ppm}$; for Pb: less than $0.15 \mathrm{ppm}$

\section{Lead, cadmium and total mercury in water}

Concentrations of $\mathrm{Pb}, \mathrm{Cd}$ and $\mathrm{tHg}$ in the waters of Lake Mainit were evaluated in seven (7) stations for southwest (SW) and northeast (NE) monsoon seasons in 2018 (Table 3). Traces of $\mathrm{Pb}$ were detected in S4 (Magtiaco) and S5 (Jaliobong) below standard limits (0.05 ppm) only during the $\mathrm{SW}$ monsoon but $\mathrm{Pb}$ were not detected across all stations during the $\mathrm{NE}$ monsoon. For $\mathrm{Cd}$, however, trace concentrations were detected only during the NE monsoon wherein Cd in waters of S6 (Dinarawan) is significantly higher $(\mathrm{P}<0.05)$ compared to the rest of study stations exceeding the safe limits (Mayag, Magpayang, Magtiaco, Jaliobong, Kalinawan) ( $\leq 0.01$ ppm $)$ [17]. Concentrations of $\mathrm{tHg}$ were not detected across the two sampling seasons in all seven tributary stations.

Table 3. $\mathrm{Pb}, \mathrm{Cd}$ and $\mathrm{Hg}$ (ppm) of water from 7 stations surrounding Lake Mainit, Philippines

\begin{tabular}{lcccc}
\hline \multicolumn{1}{c}{ Sampling sites } & Sampling period & Lead & Cadmium & Mercury \\
\hline \multirow{2}{*}{ S1 Tagbuyawan } & $\mathrm{SW}$ & $\mathrm{BDL}$ & $\mathrm{BDL}$ & $\mathrm{BDL}$ \\
& $\mathrm{NE}$ & $\mathrm{BDL}$ & $0.009 \pm 0.0^{\mathrm{d}}$ & $\mathrm{BDL}$ \\
S2 Mayag & $\mathrm{SW}$ & $\mathrm{BDL}$ & $\mathrm{BDL}$ & $\mathrm{BDL}$ \\
& $\mathrm{NE}$ & $\mathrm{BDL}$ & $0.016 \pm 0.0^{\mathrm{c}}$ & $\mathrm{BDL}$ \\
S3 Magpayang & $\mathrm{SW}$ & $\mathrm{BDL}$ & $\mathrm{BDL}$ & $\mathrm{BDL}$ \\
& $\mathrm{NE}$ & $\mathrm{BDL}$ & $0.013 \pm 0.0^{\mathrm{c}}$ & $\mathrm{BDL}$ \\
S4 Magtiaco & $\mathrm{SW}$ & $0.013 \pm 0.0$ & $\mathrm{BDL}$ & $\mathrm{BDL}$ \\
& $\mathrm{NE}$ & $\mathrm{BDL}$ & $0.018 \pm 0.0^{\mathrm{c}}$ & $\mathrm{BDL}$ \\
S5 Jaliobong & $\mathrm{SW}$ & 0.024 & $\mathrm{BDL}$ & $\mathrm{BDL}$ \\
& $\mathrm{NE}$ & $\mathrm{BDL}$ & $0.026 \pm 0.0^{\mathrm{b}}$ & $\mathrm{BDL}$ \\
S6 Dinarawan & $\mathrm{SW}$ & $\mathrm{BDL}$ & $\mathrm{BDL}$ & $\mathrm{BDL}$ \\
& $\mathrm{NE}$ & $\mathrm{BDL}$ & $0.054 \pm 0.0^{\mathrm{a}}$ & $\mathrm{BDL}$ \\
S7 Kalinawan & $\mathrm{SW}$ & $\mathrm{BDL}$ & $\mathrm{BDL}$ & $\mathrm{BDL}$ \\
\hline DAO 2016 [17] & $\mathrm{NE}$ & $\mathrm{BDL}$ & $0.023 \pm 0.0^{\mathrm{b}}$ & $\mathrm{BDL}$ \\
\hline
\end{tabular}

$\mathrm{BDL}$ for water Pb: less than $0.01 \mathrm{ppm}$; BDL for $\mathrm{Cd}$ : less than 0.003; BDL for tHg: less than 0.02; Different letters on column indicate significant differences $(\mathrm{P}<0.05)$

\section{Lead, cadmium and total mercury in sediments}

The order of the concentration levels in sediments for the two index seasons was in the following: $\mathrm{Pb}>\mathrm{Cd}>\mathrm{tHg}$ (Table 4). Trace $\mathrm{Pb}$ concentrations were detected in sediments across all 
seven stations only during the SW monsoon with concentrations exceeding standard limits (31-91 ppm) $[18,19]$ in S6 (Dinarawan) and registered highest in S7 (Kalinawan). Pb were below detectable limits across the 7 stations during the NE monsoon. Trace concentrations of $\mathrm{Cd}$ in sediments were not detected for both NE and SW monsoons across all seven stations except a very minimal Cd detected in S7 (Kalinawan) during the SW monsoon. Trace concentrations of tHg were BDL during the NE monsoon and most of the SW monsoon, except for tHg in S4 (Magtiaco) and S7 (Kalinawan) which exceeded the $0.1 \mathrm{ppm}$ standard limit [18].

Table 4. $\mathrm{Pb}, \mathrm{Cd}$ and $\mathrm{Hg}(\mathrm{ppm})$ of sediments from 7 tributary stations surrounding Lake Mainit, Philippines

\begin{tabular}{lcccc}
\hline \multicolumn{1}{c}{ Sampling sites } & Sampling period & Lead & Cadmium & Mercury \\
\hline \multirow{2}{*}{ S1 Tagbuyawan } & SW & $15.25 \pm 0.14^{\mathrm{c}}$ & $\mathrm{BDL}$ & $\mathrm{BDL}$ \\
& $\mathrm{NE}$ & $\mathrm{BDL}$ & $\mathrm{BDL}$ & $\mathrm{BDL}$ \\
S2 Mayag & $\mathrm{SW}$ & $11.64 \pm 0.09^{\mathrm{c}}$ & $\mathrm{BDL}$ & $\mathrm{BDL}$ \\
& $\mathrm{NE}$ & $\mathrm{BDL}$ & $\mathrm{BDL}$ & $\mathrm{BDL}$ \\
S3 Magpayang & $\mathrm{SW}$ & $9.76 \pm 0.07^{\mathrm{c}}$ & $\mathrm{BDL}$ & $\mathrm{BDL}$ \\
& $\mathrm{NE}$ & $\mathrm{BDL}$ & $\mathrm{BDL}$ & $\mathrm{BDL}$ \\
S4 Magtiaco & $\mathrm{SW}$ & $15.88 \pm 0.04^{\mathrm{c}}$ & $\mathrm{BDL}$ & $0.13 \pm 0.02$ \\
& $\mathrm{NE}$ & $\mathrm{BDL}$ & $\mathrm{BDL}$ & $\mathrm{BDL}$ \\
S5 Jaliobong & $\mathrm{SW}$ & $15.79 \pm 0.05^{\mathrm{c}}$ & $\mathrm{BDL}$ & $\mathrm{BDL}$ \\
& $\mathrm{NE}$ & $\mathrm{BDL}$ & $\mathrm{BDL}$ & $\mathrm{BDL}$ \\
S6 Dinarawan & $\mathrm{SW}$ & $73.33 \pm 0.11^{\mathrm{b}}$ & $\mathrm{BDL}$ & $\mathrm{BDL}$ \\
& $\mathrm{NE}$ & $\mathrm{BDL}$ & $\mathrm{BDL}$ & $\mathrm{BDL}$ \\
S7 Kalinawan & $\mathrm{SW}$ & $238.49 \pm 0.29^{\mathrm{a}}$ & $0.93 \pm 0.10$ & $0.35 \pm 0.02$ \\
& $\mathrm{NE}$ & $\mathrm{BDL}$ & $\mathrm{BDL}$ & $\mathrm{BDL}$ \\
\hline WHO 1993 [18] & & 31 & 0.6 & 0.1 \\
CCME 1992 [19] & & 91.3 & 35 & \\
\hline BDL for $\mathrm{in}$ & & &
\end{tabular}

BDL for Pb in sediments: 0.06; BDL for Cd in sediments: less than 0.06; BDL for tHg in sediments: less than 0.02.

Different letters on column indicate significant differences $(\mathrm{P}<0.05)$

\section{Discussion}

This cross-sectional study and its scope is limited to assessing the heavy metals lead, cadmium and total mercury in ten representative fauna of Lake Mainit during the period of investigation. Lake Mainit has over twenty freshwater fish species [2]. The accumulation of $\mathrm{Pb}$ in the muscles in three important fish species $(O$. niloticus, G. giuris and $C$. striata) were relatively low and are below the permissible standards [15]. The striped snakehead Channa striata, locally known as haluan in Lake Mainit is considered as an invasive alien species (IAS) in most countries and is one of the most abundant fishes in the lake, next to G. giuris and O. niloticus that are sought after and sold predominantly in the local markets of Lake Mainit. The trophic preference of $C$. striata as a carnivore (preferring fish and non-arthropod insects) explains its tendency to bioaccumulate mercury and other metals in many freshwater studies [20, 21].

Among all aquatic fauna assessed, the common riverine crab Sundathelpusa sp. which is ubiquitous in most shorelines of lake Mainit exceeded $\mathrm{Pb}$ safe concentrations. Riverine crabs are generally opportunistic omnivores, with a wide range of diet and exposure to many substrates, both land, water and sediments, hence, they could serve as sentinel bioindicator species for bioaccumulation. In Eerste River, South Africa, small sized Potamonautes perlatus accumulated more $\mathrm{Pb}$ and $\mathrm{Cd}$ than the larger crabs, even accumulating higher $\mathrm{Pb}$ in its body than levels of $\mathrm{Pb}$ in the river water and sediments [22]. A sentinel crab Macrophthalmus depressus from highly impacted coastal zone in Pakistan also showed a significant increase $(\mathrm{p}<0.05)$ with the exposure $\mathrm{Pb}$ levels in sediment, which indicated the potential of crab as a bioindicator of $\mathrm{Pb}$ contamination [23]. Nonetheless, studies show the heavy metal bioaccumulation in aquatic organism may be size, age, 
and species-dependent $[24,25,26]$ among other environmental factors, hence, survey utilizing other species and other metals are encouraged in future studies in Lake Mainit.

The current study reported undetected water $\mathrm{Pb}$ levels in most sections of the lake except for Magtiaco and Jaliobong--- a similar observation in 2003 by Tumanda et al [9] where water Pb were mostly undetected or very low. The highest observed water $\mathrm{Pb}$ concentration $(0.02 \mathrm{ppm})$ is lower than the reported $0.2 \mathrm{ppm}$ threshold $\mathrm{Pb}$ that could cause adverse effects in aquatic fauna including fish growth and production [27, 15]. Nonetheless, consistent detection of $\mathrm{Pb}$ in sediments with concentrations exceeding safe limits in Dinarawan and Kalinawan during the southwest (mostly dry months) monsoon of 2018 confirm that $\mathrm{Pb}$ have actually settled at the bottom of the lake. As the draining basin (as it catches majority of the water from Lake Mainit), the sediment samples from the Kalinawan River were potentially disturbed by the varying flow rates of the water being drained from Lake Mainit, and thus may have contributed to the changes in the physical disturbance of sediments in the area. Such changes may also affect the physical environment, such as $\mathrm{pH}$ and DO, which could affect the release of heavy metals which are mainly affected by the heavy metal speciation, and the contents of different species were different [28]. Overturn brought about by rainfall, wind patterns and other factors could potentially expose aquatic fauna to $\mathrm{Pb}$ that have settled in the sediments and could pose danger to aquatic biota. Lead generally does not bioaccumulate in aquatic organisms [29] and so consumers could take up $\mathrm{Pb}$-contaminated food but without biomagnification [30].

Trace concentrations of cadmium were only detected in the water during the northeast monsoon, with most levels exceeding threshold limits $(0.01 \mathrm{ppm})$ [17]. Cadmium in the sediments were either undetected or very low. In 2003, tests on $\mathrm{Cd}$ in waters of Lake Mainit ranged from 0.001-0.004 ppm with relatively higher $\mathrm{Cd}$ concentrations related to agriculture related activities that might have contributed to the high $\mathrm{Cd}$ in the waters of these stations [9].

Lake Mainit has intensive farming activities and $\mathrm{Cd}$ from phosphate fertilizers and pesticides applied to these agricultural areas may have contributed to $\mathrm{Cd}$ pollution which might have leached into the lake. A variety of human activities involving mining, processing or use of Cd-containing substances are some of the known anthropogenic sources of $\mathrm{Cd}$. The NE monsoon months (November, December) when the water and sediments were collected coincide with beginning of the rainy season as well as the end of the second cropping season of rice and corn in most sections surrounding the lake which could explain the $\mathrm{Cd}$ detected as it may have leached into the lake water. The presence of $\mathrm{Cd}$ in water samples may have serious ecotoxicological implication. Cadmium is noted to be more mobile in aquatic environments than most other heavy metals, and thus it poses serious risk to aquatic organisms [31]. Aside from anthropogenic sources, $\mathrm{Cd}$ is also introduced in aquatic ecosystem as a result of the weathering of soils and rocks and some are being released into the air through forest fires. Several studies have reported link of seasonal rice farming season with higher $\mathrm{Cd}$ in nearby freshwaters especially during the cultivating seasons [32]. In Mahaweli River, Sri Lanka, the amount of cadmium in tributaries had a significant positive correlation with the cadmium loading of the cropping system leading to chronic renal failure (CRF) associated with elevated dietary cadmium (Cd) among 9000 patients from nearby farming communities [33].

Determination of mercury was purposely included from fauna, water and sediment samples because of the many small scale gold mining activities which could contributed $\mathrm{Hg}$ into the lake. While total mercury content were undetected in the aquatic fauna and waters of Lake Mainit, $\mathrm{tHg}$ was found exceeding safe limits in Magtiaco and Kalinawan sediment samples during the southwest monsoon. Small scale gold mining activity was noted upstream of the Magtiaco station. Lake water empties into the Kalinawan River which may explain the high tHg level in sediments in the area.

Mercury entering the aquatic environment, either sourced from anthropogenic activity or from natural geologic sources may be converted to methylmercury $(\mathrm{MeHg})$ depending on the lake's condition ( $\mathrm{pH}$, dissolved oxygen, bacteria) and can be bioaccumulated by fish and other aquatic species [34]. Determination of $\mathrm{MeHg}$ in a wide array of fishes from the lake should be looked into in future studies to assess the health and safety of these rich fishery resource for consumption. 


\section{Conclusions}

Lake Mainit is under pressure due to various human activities; agricultural, industrial, municipal and domestic wastes from human settlements, among others characterized by elevated concentration of $\mathrm{Cd}$ in water and $\mathrm{Pb}$ and $\mathrm{tHg}$ in sediments. These results corroborate to the fact that $\mathrm{Cd}$ is more mobile in aquatic ecosystem as compared to most of the metals. On the other hand, $\mathrm{Pb}$ was also detected in some of the aquatic fauna such as $V$. angularis and Sundathelpusa sp. $(>0.5 \mathrm{ppm})$. The results suggest that potential bioaccumulation of $\mathrm{Pb}$ is inevitable if pollution sources cannot be controlled if not eliminated. The presence of tHg in sediments posed great environmental risk since sediment-deposited $\mathrm{Hg}$ may be potentially speciated to organic form of mercury $(\mathrm{MeHg})$ which is more toxic and potent. The conduct of a continuous monitoring of the contamination level of heavy metals and speciation analysis of the identified metals in the sediment samples are recommended to give a concrete ecotoxicological risk assessment.

\section{Conflict of Interest}

The authors declare that there are no conflicts of interest

\section{Acknowledgments}

This project is funded by the Commission on Higher Education (CHED K-12 DARE TO) Project.

\section{References}

[1] Lake Mainit Development Alliance LMDA.Lake Mainit. https://lmda.wordpress.com/aboutlake-mainit/. (2010).

[2] A.B. De Guzman et al. Sustainable Fisheries Management Program for Lake Mainit: Phase I: Rapid Resource Assessment. Inception Report. Prepared by MSU at Naawan for the PCAMRD-DOST. (2008) 75p.

[3] W. Ouyang et al. Heavy metal loss from agricultural watershed to aquatic system: A scientometrics review. Science of The Total Environment, 637 (2018), 208-220.

[4] S. Rajeshkumar, X. Li. Bioaccumulation of heavy metals in fish species from the Meiliang Bay, Taihu Lake, China. Toxicology Reports, 5, (2018), 288-295.

[5] A.O. Numbere. Bioaccumulation of Total Hydrocarbon and Heavy Metals in Body Parts of the West African Red Mangrove Crab (Goniopsis pelii) in the Niger Delta, Nigeria. International Letters of Natural Sciences, 75 (2019), 1-12.

[6] Cabuga et al. Levels of cadmium, copper, lead, nickel and mercury in the muscles of Pigok (Mesopristes cancellatus) and sediments collected at lower Agusan River Basin, Brgy. Pagatpatan, Butuan City, Agusan Del Norte, Philippines. International Journal of Fisheries \& Aquatic Studies, 4.4(2016), 206-215.

[7] C.Vu et al. Bioaccumulation and potential sources of heavy metal contamination in fish species in Taiwan: assessment and possible human health implications. Environmental Science \& Pollution Research, 24.23(2017), 19422-19434.

[8] Y. Niu et al. Assessment of heavy metal pollution in sediments of inflow rivers to Lake Taihu, China. Bulletin of Environmental Contamination \& Toxicology, 95.(2015), 618-623.

[9] M.I Tumanda et al. Limnological and Water Quality Assessment of the Lake Mainit, Mindanao State University, Naawan. (2003).

[10] R. Catoto. Minda News, This is our Mindanao, 20 th $^{\text {th }}$ December 2015 
[11] N. Leonardo et al. Heavy metals in lake water: A review on occurrence and analytical determination, International Journal of Environmental Analytical Chemistry, 98. 6 (2018), 536-554.

[12] S. Shanbehzadeh et al. Heavy Metals in Water and Sediment: A Case Study of Tembi River, Journal of Environmental \& Public Health, (2014), 1-5.

[13] S. Simpson, G. Batley. Sediment Quality Assessment: A Practical Guide, 2nd Ed (2016). CSIRO Publishing.

[14] G.W. Latimer, Jr. Official Methods of Analysis of AOAC International, 21st Ed (2019).

[15] Food and Agriculture Organization (FAO). FAO, fishery circular. 464 (1983) 5-100.

[16] Food and Agriculture Organization/ World Health Organization (FAO/WHO). List of Maximum Levels Recommended for Contaminants by the Joint FAO/WHO Codex Alimentarius Commission, Second Series. CAC/FAL Rome 3 (1984) 1-8.

[17] Department of Environment and Natural Resources (DENR). DAO 2016-08: Water Quality Guidelines and General Effluent Standards of 2016. https://pab.emb.gov.ph/wpcontent/uploads/2017/07/DAO-2016-08-WQG-and-GES.pdf

[18] World Health Organization (WHO) Guidelines for Drinking Water Quality. 2nd Edn., Recommendations, WHO, Geneva, Vol. 1.(1993).

[19] CCME (Canadian Council of Ministers of the Environment). Canadian Water Quality Guidelines, prepared by the Task Force on Water Quality Guidelines of the Canadian Council of Ministers of the Environment, Eco-Health Branch, Ottawa, Ontario, Canada. (1992).

[20] R. Kuppu et al. A study on the impact of water quality on the murrel fish Channa striata and Channa punctata from three major Southern Tamilnadu rivers, India. RSC Advances 8.21 (2018): 11375-11387

[21] N. Paul et al. Lead toxicity on non-specific immune mechanisms of freshwater fish Channa punctatus. Aquatic Toxicology, 152 (2014), 105-112.

[22] A.J. Reinecke et al. Uptake and Distribution of Lead $(\mathrm{Pb})$ and Cadmium $(\mathrm{Cd})$ in the Freshwater Crab, Potamonautes perlatus (Crustacea) in the Eerste River, South Africa. Water, Air, \& Soil Pollution, 145 (2003), 395-408.

[23] N. Saher et al. Occurrence of heavy metals in sediment and their bioaccumulation in sentinel crab (Macrophthalmus depressus) from highly impacted coastal zone. Chemosphere, 221 (2019) 89-98.

[24] G. Pandey, S. Madhuri. Heavy metals causing toxicity in animals and fishes. Research Journal of Animal, Veterinary \& Fishery Sciences, 2.2 (2014). 17-23.

[25] C. Kasimoglu. The effect of fish size, age and condition factor on the contents of seven essential elements in Anguilla anguilla from Tersakan Stream Mugla (Turkey). Journal of Pollution Effects \& Control, 2.2 (2014), 123-129.

[26] O. Canpolat, O. (2013). The determination of some heavy metals and minerals in the tissues and organs of the Capoeta umbla fish species in relation to body size, sex, and age. Ekoloji, 22.87 (2013), 64-72.

[27] J.H. Kim, J.C. Kang. The lead accumulation and hematological findings in juvenile rock fish Sebastes schlegelii exposed to the dietary lead (II) concentrations. Ecotoxicology \& Environmental Safety, 115 (2015), 33-39

[28] $\mathrm{H} \mathrm{Li}$ et. al. Effect of pH, Temperature, Dissolved Oxygen, and Flow Rate of Overlying Water on Heavy Metals Release from Storm Sewer Sediments, Journal of Chemistry, (2013), 1-11) 
[29] C.Y. Chen, C.L. Folt. Bioaccumulation and diminution of arsenic and lead in a freshwater food web. Environmental Science \& Technology, 34.18. (2000), 3878-3884.

[30] WHO.Environmental Health Criteria No 165, Lead, inorganic. IPCS, World Health Organisation, Geneva. (1995).

[31] A.A. El-Badry. Distribution of heavy metals in contaminated water and bottom deposits of Manzala Lake, Egypt. Journal of Environment Analytical Toxicology, 6.1 (2016), 1-8.

[32] P.C.T. Perera et al. Arsenic and cadmium contamination in water, sediments and fish is a consequence of paddy cultivation: Evidence of river pollution in Sri Lanka. Achievements in the Life Sciences, 10.2 (2016), 144-160.

[33] J.M.R.S. Bandara et al. Pollution of River Mahaweli and farmlands under irrigation by cadmium from agricultural inputs leading to a chronic renal failure epidemic among farmers in NCP, Sri Lanka. Environmental Geochemistry \& Health, 33.5 (2011), 439-453.

[34] D.C. Depew et al. Toxicity of dietary methylmercury to fish: derivation of ecologically meaningful threshold concentrations. Environmental Toxicology \& Chemistry, 31(2012), 1536-1547. 